\title{
O Corpus Paulinum no Cânon do Novo Testamento
}

\author{
The Corpus Paulinum in the New Testament Canon
}

\author{
Waldecir Gonzaga
}

\section{Resumo}

Hoje, católicos, ortodoxos e protestantes aceitam todos o mesmo Cânon do Novo Testamento (NT) e na ordem em que se encontram os 27 livros do Corpus Biblicum do NT; mas nem sempre foi assim e nem sequer a ordem que temos hoje é a mesma em todos os Catálogos antigos que temos à nossa disposição. Por isso, a fim de nos ajudar na compreensão desta temática, queremos oferecer um ensaio acerca deste conjunto de Cartas do NT, intituladas Cartas Paulinas, que desde a antiguidade sempre encontrou aceitação seja no Corpus do NT seja em seu próprio Corpus, internamente falando, sendo também o grupo de Cartas do NT mais estudado e comentado, haja vista a vasta literatura que temos à disposição, seja no campo Católico, como no Ortodoxo e no Protestante, que sempre aceitaram a canonicidade das Cartas Paulinas. O único texto dissonante foi a Carta aos Hebreus, que desde o Período Patrístico sempre encontrou problemas na aceitação de que fosse de autoria paulina. Além disso, o que os estudiosos modernos têm levantado é a questão de que Paulo tenha ou não escrito diretamente todos os textos a ele atribuídos. Além de que, segundo a maioria dos estudiosos, entre as atuais Cartas Paulinas, na verdade, nós temos sete cartas que são autenticamente Paulinas, três consideradas Deuteropaulinas e três chamadas de Pastorais. Enfim, nossa intenção é aquela de oferecer uma colaboração acerca da estrutura do Canon Paulinum dentro do Canon Novi Testamenti, seja na estrutura seja na distribuição do mesmo enquanto ordem de ocorrência e sequência dentro do Cânon do NT; por isso, oferecemos também alguns gráficos 
ilustrativos acerca de seu arranjo, por acreditar que isso pode facilitar a visualização e assimilação do conteúdo.

Palavras-chave: Cânon Paulino. Arranjo/Ordem. Corpus Paulinum. Canônico. Novo Testamento.

\begin{abstract}
Today, Catholics, Orthodox and Protestants accept all the same canon of the New Testament (NT) and in the order they are 27 of the Corpus Biblicum NT books; but it was not always like that and not even the order we have today is the same in all the ancient Catalogs, we have at our disposal. Therefore, in order to help us understand this issue, we want to offer an essay about this NT set of letters, entitled Letters Pauline, that since antiquity has always found acceptance is in the NT Corpus is at your own Corpus, internally speaking, also being the NT Letters group most studied and commented, given the vast literature available to us, whether in the Catholic field, as in the Orthodox and Protestant, who always accepted the canonicity of the Pauline Letters. The only dissonant text was the Letter to the Hebrews, which from the Patristic period always found acceptance problems that were of Pauline authorship. Also, what modern scholars have raised is the question that Paul not has written or directly all the texts attributed to him. Apart from that, according to most scholars, among the current Pauline letters, in fact, we have seven letters that are authentically Pauline, three considered Deuteropaulines and three calls Pastoral. Finally, our intention is that of providing a collaboration about the structure of Canon Paulinum within Canon Testamenti Novi, in the structure is the same as the distribution order and sequence of occurrence within the NT Canon; so also we offer some illustrative graphics about their arrangement, believing that this can facilitate the visualization and assimilation of content.
\end{abstract}

Keywords: Pauline Canon. Arrangement/Order. Corpus Paulinum. Canonic. New Testament. 


\section{Introdução}

Dos 27 livros que temos em todo o Novo Testamente 21 são Cartas e Epístolas, sendo em sua maioria as Cartas Paulinas (13) e as Cartas Católicas (7), além de que as Cartas Paulinas foram aceitas como canônicas desde o início, inclusive com o reconhecimento de vários Padres da Igreja que foram citando-as ${ }^{1}$, e as Cartas Católicas encontraram dificuldades para entrar no Cânon $^{2}$ do Novo Testamento (NT). Neste sentido, um personagem emblemático foi Marcião, que em seu Cânon Bíblico, recusando todo o AT e aceitando apenas alguns textos do NT, aceitou tão somente o Evangelho de Lucas e 10 Cartas Paulinas ${ }^{3}$. Aliás, as Cartas Paulinas formaram o primeiro conjunto dos textos do NT estabelecido e usado pela Igreja ${ }^{4}$, sendo Paulo também o primeiro autor do NT, antes mesmo de qualquer Evangelista ${ }^{5}$, ainda que algumas de suas Cartas encontrem resistência em serem aceitas como autenticamente paulinas, mesmo nos dias atuais ${ }^{6}$. Fora as 13 Cartas Paulinas e 7 Católicas,

\footnotetext{
${ }^{1}$ SACCHI, A. e Collaboratori. Lettere Paoline e Altre Lettere. Torino: Elle Di Ci, 1995, pp. 39-40; CABALLERO, J. L. "El Canon Paulino. Consideraciones en torno a la naturaliza y la formación del Canon del Nuevo Testamento". Scripta Theologica 41 (2009/3), p. 900; GAMBLE, H. Y. "The Redaction of the Pauline Letters and the Formation of the Pauline Corpus". JBL 49 (1975), p. 406; FOSTER, L. "The Earliest Collection of Paul's Epistles". BETS (1956), p. 46.

${ }^{2}$ Para uma maior ideia sobre o Cânon do NT e, especialmente do Cânon Paulino, indicamos o verbete PATZIA, A. G. "Cânon". In: HAWTHORNE, G. F.; MARTIN, R. P.; REID, D. G. (Orgs.). Dicionário de Paulo e suas Cartas. São Paulo: Vida Nova-Paulus-Loyola, 2008, pp. 169-177.
}

${ }^{3}$ SACCHI, A. e Collaboratori. Lettere Paoline e altre Lettere, p. 40.

${ }^{4}$ PORTER, S. E. "When and How was the Pauline Canon Compiled? An Assessment of Theories”. In: PORTER, S. E. The Pauline Canon. Atlanta: Society of Biblical Literature, 2009, pp. 95.99; HOLMES, M. W. "Crítica Textual”. In: HAWTHORNE, G. F.; MARTIN, R. P.; REID, D. G. (Orgs.). Dicionário de Paulo e suas Cartas. São Paulo: Vida Nova-Paulus-Loyola, 2008, pp. 337-341, fala de três etapas para a história textual do Cânon Paulino, que fora se formando gradativamente: a) A etapa do corpus; b) Do corpus para tipos textuais; c) $O$ surgimento de tipos textuais.

${ }^{5}$ CABAllero J. L. "El Canon Paulino", p. 922.

${ }^{6}$ AAGESON, J. W. "The Pastoral Epistles, Apostolic Authority, and the Development of the Pauline Scriptures". In: PORTER, S. E. The Pauline Canon. Atlanta: Society of Biblical Literature, 2009, p. 17; O’NEILL, J. C. Paul Wrote some of all, but not all of any. In: PORTER, S. E. The Pauline Canon. Atlanta: Society of Biblical Literature, 2009, p.167; BROWN, R. E.; COLLINS, R. F. "O Cânone do Novo Testamento". In: BROWN, R. E.; FITZMYER, J. A.; MURPHY, R. E. Novo Comentário Bíblico São Jerônimo do Novo Testamento e Artigos Sistemáticos. Santo André: Academia Cristã, 2011, p. 927; FITZMYER, J. A. "Introdução às Epístolas do Novo Testamento”. In: BROWN, R. E.; FITZMYER, J. A.; MURPHY, R. E. Novo 
no NT nós temos apenas mais uma, a saber, a Carta aos Hebreus, de autoria muito discutida desde o mundo antigo e hoje tida pelos estudiosos como não paulina $^{7}$. De tal forma que quando olhamos para todo o NT, temos a seguinte divisão, já clássica desde o Período da Patrística, ainda que nem sempre a ordem tenha sido a mesma inicialmente: Evangelhos (4: Mateus, Marcos, Lucas e João); Atos dos Apóstolos; Cartas Paulinas (13: Romanos, 1 Coríntios, 2 Coríntios, Gálatas, Efésios, Filipenses, Colossenses, 1 Tessalonicenses, 2 Tessalonicenses, 1 Timóteo, 2 Timóteo, Tito e Filemon) ${ }^{8}$; Carta aos Hebreus; Cartas Católicas (7: Tiago, 1 Pedro, 2 Pedro, 1 João, 2 João, 3 João e Judas) e Apocalipse; e aqui é sempre bom lembrar que alguns destes textos encontraram dificuldades para entrar no Cânon do NT, os chamados Deuterocanônicos do $\mathrm{NT}^{9}$ (Hebreus, Tiago, 2 Pedro, 1 e 2 João, Judas e Apocalipse), como indicamos nos gráficos abaixo, a fim de melhor ajudar na assimilação do conteúdo apresentado a partir dos mesmos ${ }^{10}$.

As Cartas Paulinas contam com alguns textos mais longos, outros relativamente breves e outros muito breves, desde Romanos, a maior, passando por

Comentário Bíblico São Jerônimo do Novo Testamento e Artigos Sistemáticos. Santo André: Academia Cristã, 2011, p. 403; BALLARINI, T. "São Paulo e as suas Cartas em Geral”. In: BALLARINI, T. Introdução à Bíblia. Vol V/1. Petrópolis: Vozes, 1969, p. 194; SANCHEZ BOSCH, J. Escritos Paulinos. Vol. 7. São Paulo: Ave Maria, 2002, p. 13; LONA, H. Introducción a Pablo. El Autor, Las Cartas, El Paulinismo. Buenos Aires: Editorial Claretiana, 2011, pp. 41-44; BORING, M. E. Uma Introdução ao Novo Testamento: História, Literatura, Teologia. Questões Introdutórias do Novo Testamento e Escritos Paulinos. Vol. I. Santo André: Academia Cristã - Paulus, 2016, pp. 624-673.

${ }^{7}$ HARDING, M. "Disputed and Undisputed Letters of Paul”. In: PORTER, S. E. The Pauline Canon. Atlanta: Society of Biblical Literature, 2009, p. 135; FITZMYER, J. A. "Introdução às Epístolas do Novo Testamento", p. 404.

${ }^{8}$ Podemos dividir o Epistolário Paulino entre: a) escritos tidos pela maioria dos estudiosos como autenticamente Paulinos (Romanos, 1 e 2 Coríntios, Gálatas, 1 Tessalonicenses, Filipenses e Filemon); b) escritos tidos como de autenticidade paulina duvidosa (Efésios, Colossenses e 2 Tessalonicenses; chamados de cartas Deuteropaulinas); e c) escritos pseudônimos ou de atribuição paulina, mas que não são autenticamente paulinos (1 e 2 Timóteo e Tito, chamados de Pastorais). É sempre bom lembrar que entre os critérios de aceitação de um texto tínhamos: a) Apostolicidade; b) Ortodoxia ou Regra de Fé; c) Antiguidade; d) Uso litúrgico e adaptabilidade nas igrejas locais, tendo em vista a capacidade de alimentar a vida dos fiéis.

${ }^{9}$ MANNUCCI, V. Bíblia, Palavra de Deus. Curso de introdução à Sagrada Escritura. São Paulo: Paulus, 2008, p. 223.

${ }^{10}$ Para uma melhor visualização da temática sobre as várias listas dos textos do Cânon do NT sugerimos conferir temática no Enquiridion Bíblico que indicamos em nossas Referências Bibliográficas, no final deste texto (ENQUIRIDION BÍBLICO. Documentos de la Iglesia sobre la sagrada Escritura. Madrid: BAC, 2010). Para a questão de aceitação ou não de alguns dos livros que compreendem o Corpus Paulinum, indicamos os gráficos neste nosso ensaio. 
Filipenses, uma média, até Filemon, a mais breve de todas. Sua ordem em nossas Bíblias modernas segue a ordem fixada pela Vulgata, que não é uma ordem cronológica e sim de grandeza, visto que o seu comprimento vai diminuindo de Romanos a Filemon ${ }^{11}$. Alguns falam também de ordem de importância por motivo de escrita ou de destinação, visto que primeiro temos as quatro grandes Epístolas (Rm, 1 e 2 Cor, Gl), em seguida temos as Epístolas do Cativeiro (Ef, $\mathrm{Fl}, \mathrm{Cl}$ ), seguida pelas 2 Epístolas aos Tessalonicenses, encerrando o ciclo das Epístolas enviadas às sete Igrejas, para depois termos as Epístolas enviadas a pessoas privadas ( 1 e $2 \mathrm{Tm}, \mathrm{Tt}, \mathrm{Fm})^{12}$; porém, também é verdade que a questão da ordem respeitando a questão da maior à menor encontra a dificuldade das Pastorais e de Hebreus, que inicialmente era tida como Paulina ${ }^{13}$. Mas, de todos os modos, as Cartas Paulinas constituem um conjunto importante em toda a literatura do NT, que nos revelam aspectos interessantes da Igreja Primitiva e mesmo em sua relação com os demais escritos do NT, bem como sobre a pessoa do próprio Paulo, tido por muitos, inclusive, como o primeiro teólogo cristão, que "soube moldar seu ensino em forma de carta", como nos recorda J.A. Fitzmyer ${ }^{14}$, visto as necessidades da evangelização ${ }^{15}$ e não apenas uma opção de método de evangelização. Como nos recorda E. Cothenet, Paulo é um missionário que se torna também escritor ${ }^{16}$.

Enquanto que as Cartas Católicas despertaram menos interesse nos estudos ficando, com isso, mais desconhecidas do público em geral, causando deficiência até mesmo no conhecimento de situações bastante diferentes daquelas que temos no epistolário paulino ${ }^{17}$, as Cartas Paulinas sempre despertaram um interesse muito maior. Neste sentido, cremos não ser exagero afirmar que o conjunto das Cartas do Corpus Paulinum é aquele que sempre despertou menos dificuldades de aceitação no Cânon ao longo de sua história, sendo

\footnotetext{
${ }^{11}$ FITZMYER, J. A. "Introdução às Epístolas do Novo Testamento”, p. 405.

${ }^{12}$ CERFAUX, L.; CAMBIER, J. “O Corpus Paulino”. In: ROBERT, A.; FEUILLET, A. Introdução à Bíblia. Vol. IV. Novo Testamento, Parte II: Corpus Paulino. Petrópolis: Vozes, 1968, p. 14; GOSWELL, G. "The Order of the Books of the New Testament". JETS 53/2 (2010), pp. $235-240$.

${ }^{13}$ SANCHEZ BOSCH, J. Escritos Paulinos, p. 13; BALLARINI, T. "São Paulo e as suas Cartas em Geral", p. 195.

${ }^{14}$ FITZMYER, J. A. "Introdução às Epístolas do Novo Testamento", p. 403.

${ }^{15}$ BALLARINI, T. "São Paulo e as suas Cartas em Geral”, p. 194.

${ }^{16}$ COTHENET, T. São Paulo e seu Tempo. São Paulo: Paulinas, 1985, pp. 25-37; SACCHI, A. e Collaboratori. Lettere Paoline, pp. 39-52.

${ }^{17}$ BALLARINI, T. "São Paulo e as suas Cartas em Geral”, pp. 289-290.
} 
admitido bem mais cedo e com muito menores dificuldades que o Corpus $\mathrm{Ca}$ tholicum $^{18}$, inclusive pelos Reformadores, que também preferiram as Cartas Paulinas e levantaram dificuldades em relação a algumas Cartas Católicas ${ }^{19}$.

\section{Livros do Cânon do NT em alguns autores antigos e na Vulgata}

Aqui abaixo, em sistema de gráfico, nós tentamos reproduzir os livros do Novo Testamento tratados e aceitos pelos cristãos em geral como Escrituras Canônicas desde os primeiros escritores e que conservamos como tal até hoje em nosso Cânon do NT, que também poderíamos chamar de Escrituras genuínas ou normativas para os cristãos, visto que o Cânon revela quais livros são normativos para os fiéis e quais não são. Este é um gráfico ilustrativo, onde citamos apenas alguns, seguindo o critério de colocar o Cânon de Marcião, que é chamado o Cânon "mutilado"20, visto que ele aceita tão somente o Evangelho de Lucas e 10 Cartas Paulinas, recusando os Evangelhos de Mateus, Marcos e João, bem como as três Cartas Pastorais, a Carta aos Hebreus, as sete Cartas Católicas e o livro do Apocalipse, na intenção de expulgar do Cânon todos os vestígios e elementos judaicos (anti-judaismo) ${ }^{21}$; em seguida, citamos dois Padres da Igreja Oriental: o Cânon de Atanásio, que é a mais antiga lista completa do NT, bem como o Cânon de Gregório Naziano, que, seguindo vários orientais, não cita o Apocalipse; depois, citamos dois Padres Ocidentais, Jerônimo e Agostinho, que também trazem o Cânon do NT completo, bem como a Versão da Vulgata, que é aquela que vai ser normativa para o Ocidente durante muitos séculos, e que traz o Cânon do NT que a Igreja segue até hoje, inclusive em sua ordem e aranjo no catálogo bíblico. Vale a pena recordar ainda, que a Carta aos Hebreus encontrou dificuldades de aceitação para entrar no Cânon do NT sobretudo no Ocidente, enquanto que Apocalipse sobretudo no Oriente.

A fim de melhor entender o gráfico, basta perceber os livros indicados em cada coluna, sendo que o espaço em branco significa que o autor não citou o livro ou o recusou expressamente, como é o caso de Marcião que aceitou

\footnotetext{
${ }^{18}$ SACCHI, A. e Collaboratori. Lettere Paoline e altre Lettere, p. 235.

${ }^{19}$ Sugerimos conferir a problemática no Enquiridion Bíblico para o que diz respeito ao Cânon do NT presente no Concílio de Trento como resposta à problemática levantada pelos Pais da Reforma em relação a algumas Cartas Católicas.

${ }^{20}$ HARDING, M. "Disputed and Undisputed Letters of Paul”, p. 132; CARROL, K. L. "The expansion of the Pauline Corpus", JBL 59 (1953), pp. 230-237, 233.

${ }^{21}$ PORTER, S.E. "When and How was the Pauline Canon Compiled? An Assessment of Theories", p. 105; CARROL, K. L. “The expansion of the Pauline Corpus”. JBL 59 (1953), p. 233.
} 
apenas o Evangelho de Lucas e 10 das cartas Paulinas, recusando as 3 Pastorais, Hebreus, as Católicas e o Apocalipse, ou de Gregório Naziano, que recusou Apocalipse. Este gráfico nos apresenta o conjunto da obra toda do NT, na sequência que temos em nossas Bíblias hoje e não na ordem que o autor citou em seu Cânon, apenas para melhor nos ajudar a visualizar quais livros foram aceitos e quais livros foram recusados por cada autor; já o arranjo segundo cada um deles nós apresentamos no gráfico seguinte a este, onde é possível ver a distribuição que cada um dos mesmos autores citados deu dentro de "seu" Cânon, indicando, inclusive, a ordem de valor dos mesmos.

\begin{tabular}{|c|c|c|c|c|c|}
\hline $\begin{array}{l}\text { Marcião } \\
\text { (140) }\end{array}$ & $\begin{array}{l}\text { Atanásio } \\
(367)\end{array}$ & $\begin{array}{l}\text { Gregório } \\
(380)\end{array}$ & $\begin{array}{l}\text { Jerônimo } \\
\text { (393) }\end{array}$ & $\begin{array}{l}\text { Agostinho } \\
\text { (397) }\end{array}$ & $\begin{array}{c}\text { Versão da Vulgata } \\
\text { (Final Séc. IV) }\end{array}$ \\
\hline & Mateus & Mateus & Mateus & Mateus & Mateus \\
\hline & Marcos & Marcos & Marcos & Marcos & Marcos \\
\hline \multirow[t]{3}{*}{ Lucas } & Lucas & Lucas & Lucas & Lucas & Lucas \\
\hline & João & João & João & João & João \\
\hline & Actos & Atos & Atos & Atos & Atos dos Apóst. \\
\hline Romanos & Romanos & Romanos & Romanos & Romanos & Romanos \\
\hline 1 Coríntios & 1 Coríntios & 1 Coríntios & 1 Coríntios & 1 Coríntios & 1 Coríntios \\
\hline 2 Coríntios & 2 Coríntios & 2 Coríntios & 2 Coríntios & 2 Coríntios & 2 Coríntios \\
\hline Gálatas & Gálatas & Gálatas & Gálatas & Gálatas & Gálatas \\
\hline Efésios (Ld) & Efésios & Efésios & Efésios & Efésios & Efésios \\
\hline Filipenses & Filipenses & Filipenses & Filipenses & Filipenses & Filipenses \\
\hline Colossenses & Colossenses & Colossenses & Colossenses & Colossenses & Colossenses \\
\hline 1 Tessalon. & 1 Tessalon. & 1 Tessalon. & 1 Tessalon. & 1 Tessalon. & 1 Tessalon. \\
\hline \multirow[t]{4}{*}{2 Tessalon. } & 2 Tessalon. & 2 Tessalon. & 2 Tessalon. & 2 Tessalon. & 2 Tessalon. \\
\hline & 1 Timóteo & 1 Timóteo & 1 Timóteo & 1 Timóteo & 1 Timóteo \\
\hline & 2 Timóteo & 2 Timóteo & 2 Timóteo & 2 Timóteo & 2 Timóteo \\
\hline & Tito & Tito & Tito & Tito & Tito \\
\hline \multirow[t]{10}{*}{ Filemon } & Filemon & Filemon & Filemon & Filemon & Filemon \\
\hline & Hebreus & Hebreus & Hebreus & Hebreus & Hebreus \\
\hline & Tiago & Tiago & Tiago & Tiago & Tiago \\
\hline & 1 Pedro & 1 Pedro & 1 Pedro & 1 Pedro & 1 Pedro \\
\hline & 2 Pedro & 2 Pedro & 2 Pedro & 2 Pedro & 2 Pedro \\
\hline & 1 João & 1 João & 1 João & 1 João & 1 João \\
\hline & 2 João & 2 João & 2 João & 2 João & 2 João \\
\hline & 3 João & 3 João & 3 João & 3 João & 3 João \\
\hline & Judas & Judas & Judas & Judas & Judas \\
\hline & Apocalipse & & Apocalipse & Apocalipse & Apocalipse \\
\hline
\end{tabular}




\section{Arranjo do Cânon do NT em alguns autores antigos e a Vulgata}

Este segundo gráfico apresenta o arranjo trazido por cada um dos autores bíblicos aqui citados; e nós podemos ver que nem todos trouxeram os livros do NT na mesma ordem que temos hoje, além de que trouxeram outros livros que não entraram no Cânon do NT, conforme apresentamos no quarto gráfico, quando elencamos os livros do NT mais disputados que entraram no NT (Deuterocanônicos) e aqueles que ficaram fora do Cânon do NT (Apócrifos). Além disso, podemos obsevar uma diferença entre os Padres Ocidentais e os Padres Orientais, pois o Oriente coloca as Cartas Católicas antes das Cartas Paulinas e o Ocidente coloca as Cartas Paulinas antes das Cartas Católicas, como temos em nossas Bíblias, e que foi o arranjo que perdurou até hoje. Neste sentido, no que diz respeito à sua ordem atual dentro do conjunto de todo o grupo das Cartas do NT, o Oriente deu precedência às Cartas Católicas e o Ocidente parece ter visto o grupo das Cartas Católicas como que um apêndice das Cartas Paulinas ou inferior a elas, e, por isso mesmo, as dispôs após as Cartas Paulinas, consideradas de maior valor doutrinário ${ }^{22}$.

\begin{tabular}{|l|l|l|l|l|l|}
\hline \multicolumn{1}{|c|}{$\begin{array}{c}\text { Marcião } \\
(140)^{23}\end{array}$} & \multicolumn{1}{|c|}{$\begin{array}{c}\text { Atanásio } \\
(367)^{24}\end{array}$} & \multicolumn{1}{|c|}{$\begin{array}{c}\text { Gregório } \\
(380)^{25}\end{array}$} & $\begin{array}{c}\text { Jerônimo } \\
(390)^{26}\end{array}$ & $\begin{array}{c}\text { Agostinho } \\
(393)^{27}\end{array}$ & $\begin{array}{l}\text { Versão Vulgata } \\
(\text { Final Séc. IV) }\end{array}$ \\
\hline Lucas & Mateus & Mateus & Mateus & Mateus & Mateus \\
\hline Gálatas & Marcos & Marcos & Marcos & Marcos & Marcos \\
\hline 1 Coríntios & Lucas & Lucas & Lucas & Lucas & Lucas \\
\hline 2 Coríntios & João & João & João & João & João \\
\hline Romanos & Atos & Atos & $\begin{array}{l}\text { 14 paulinas } \\
\text { Romanos }\end{array}$ & $\begin{array}{l}\text { 14 paulinas } \\
\text { Romanos }\end{array}$ & $\begin{array}{l}\text { Atos dos } \\
\text { Apóstolos }\end{array}$ \\
\hline $\begin{array}{l}1 \text { Tessaloni- } \\
\text { censes }\end{array}$ & $\begin{array}{l}7 \text { Católicas } \\
\text { Tiago }\end{array}$ & $\begin{array}{l}\text { 14 Epístolas } \\
\text { Paulinas }\end{array}$ & 1 Coríntios & 1 Coríntios & $\begin{array}{l}\text { 14 Paulinas } \\
\text { Romanos }\end{array}$ \\
\hline $\begin{array}{l}2 \text { Tessaloni- } \\
\text { censes }\end{array}$ & 1 Pedro & (não menciona) $)$ & 2 Coríntios & 2 Coríntios & 1 Coríntios \\
\hline
\end{tabular}

${ }^{22}$ A fim de se ter uma melhor ideia do arranjo no Cânon do NT segundo os Orientais: Evangelhos, Atos, Católicas, Paulo e Apocalipse, sugerimos conferir a edição do NT de WESTCOTT, B. F.; HORT, F. J. A. The New Testament in The Original Greek. London: Macmillan and Co. Limited, 1906; e para a ordem do arranjo do NT segundo os Ocidentais: Evangelhos, Atos, Paulo, Católicas e Apocalipse, como temos ainda hoje, sugerimos conferir o texto do NT de NESTLEALAND. Novum Testamentum Graece. Ed. XXVIII. Stuttgart: Deutsche Bibelgesellschaft, 2012. Há um artigo que também vale a pena ler sobre esta questão da ordem dos livros do NT, que é GOSWELL, G. "The Order of the Books of the New Testament". JETS 53/2 (2010), pp. 225-241. 


\begin{tabular}{|c|c|c|c|c|c|}
\hline $\begin{array}{c}\text { Marcião } \\
(140)^{23}\end{array}$ & $\begin{array}{c}\text { Atanásio } \\
(367)^{24}\end{array}$ & $\begin{array}{l}\text { Gregório } \\
(380)^{25}\end{array}$ & $\begin{array}{c}\text { Jerônimo } \\
(390)^{26}\end{array}$ & $\begin{array}{c}\text { Agostinho } \\
(393)^{27}\end{array}$ & \begin{tabular}{|l}
$\begin{array}{l}\text { Versão Vulgata } \\
\text { (Final Séc. IV) }\end{array}$ \\
\end{tabular} \\
\hline \begin{tabular}{|l|} 
"Laodicenses" \\
(Efésios)
\end{tabular} & 2 Pedro & & Gálatas & Gálatas & 2 Coríntios \\
\hline Colossenses & 1 João & & Efésios & Efésios & Gálatas \\
\hline Filemon & 2 João & & Filipenses & Filipenses & Efésios \\
\hline \multirow[t]{17}{*}{ Filipenses } & 3 João & & 1 Tessalon. & 1 Tessalon. & Filipenses \\
\hline & Judas & & 2 Tessalon. & 2 Tessaloni. & Colossenses \\
\hline & $\begin{array}{l}14 \text { Paulinas } \\
\text { Romanos }\end{array}$ & & Colossenses & Colossenses & 1 Tessalon. \\
\hline & 1 Coríntios & & Hebreus & 1 Timóteo & 2 Tessalon. \\
\hline & 2 Coríntios & & 1 Timóteo & 2 Timóteo & 1 Timóteo \\
\hline & Gálatas & & 2 Timóteo & Tito & 2 Timóteo \\
\hline & Efésios & & Tito & Filemon & Tito \\
\hline & Filipenses & & Filemon & Hebreus & Filemon \\
\hline & Colossenses & 7 Católicas & Atos & 1 Pedro & Hebreus \\
\hline & 1 Tessalon. & Tiago & Tiago & 2 Pedro & $\begin{array}{l}7 \text { Católicas } \\
\text { Tiago }\end{array}$ \\
\hline & 2 Tessalon. & 1 Pedro & 1 Pedro & 1 João & 1 Pedro \\
\hline & Hebreus & 2 Pedro & 2 Pedro & 2 João & 2 Pedro \\
\hline & 1 Timóteo & 1 João & 1 João & 3 João & 1 João \\
\hline & 2 Timóteo & 2 João & 2 João & Judas & 2 João \\
\hline & Tito & 3 João & 3 João & Tiago & 3 João \\
\hline & Filemon & Judas & Judas & Atos & Judas \\
\hline & Apocalipse & & Apocalipse & Apocalipse & Apocalipse \\
\hline
\end{tabular}

${ }^{23}$ CINGOLANI, S. Dizionario di Critica Testuale del Nuovo Testamento. Storia, canone, aprocrifi, paleografia. Torino: San Paolo, 2008, pp. 56-57, e à pág. 420 o Dicionário traz, numa tabela, o Cânon de Marcião na ordem que ele estabeleceu, como colocamos na tabela anterior. ${ }^{24}$ ATHANASIUS ALEXANDRINI. "Epistola XXXIX". In: MIGNE, J. P. Patrologia, series Grega, Tomus XXVI. Paris: Petit-Montrouge, 1857, pp. 1435-1438. A fim de se ter uma maior visão do Cânon de Atanásio, sugerimos a leitura do texto de ARAGIONE, G. "La lettre festale 39 d'Athanase". In: ARAGIONE, G.; JUNOD, E.; NORELLI, E. (Dir.). Le Canon du Nouveau Testament. Regards nouveaux sur l'histoire de as formation. Genève: Labor et Fides, 2005, pp. 197-219. ${ }^{25}$ GREGORII THEOLOGI. “Theologica, Liber I, Sectio I, Poemata Dogmatica, Carmina XII”. In: MIGNE, J. P. Patrologia, series Grega, Tomus XXXVII, Paris: Petit-Montrouge, 1862, pp. 471-474. ${ }^{26}$ AURELII AUGUSTINI. "Doctrina Christiana, Caput VIII: Libri canonici”. In: MIGNE, J. P. Patrologia Migne Latina. Tomus XXXIV. Paris: Petit-Montrouge, 1841, pp. 40-41.

${ }^{27}$ EUSEBII HIERONIMY. "Epistola LIII”. In: MIGNE, J. P. Patrologia, series Latina, Tomus XXII. Paris: Petit-Montrouge, 1845, pp. 540-549.

${ }^{28}$ BIBLIA SACRA. Vulgatae Editionis. Sixti V Pontificis Maximi et Clementis VIII. Parisiis: Bibliopolas, 1869. 


\section{Livros do NT mais discutidos na Igreja Primitiva}

A lista e a tabela abaixo têm como intento, em primeiro lugar, mostrar que as Cartas Paulinas não encontraram dificuldades para serem aceitas no Cânon, e, em segundo lugar, mostrar quais dos livros do NT eram disputados, a não ser Hebreus, que, porém, não é paulina; também tem o intento de conferir quais destes escritos entraram no Cânon e quais foram os outros que ficaram incluídos em alguns catálogos de livros como sendo canônicos até o séc. VIII, tendo como último Padre da Igreja Oriental deste período João Damasceno. Nós procuramos oferecer apenas alguns dos vários catálogos, já que todos seria delongar bastante a temática ${ }^{29}$. Mas cremos que a partir desta tabela se poderá realizar outras com os demais catálogos existentes neste livros, seja em relação aos livros Canônicos, seja em relação aos Deuterocanônicos do AT e do NT, seja, enfim, em relação aos apócrifos ou pseudoepígrafos.

Aqui no primeiro quadro, nesta lista, na coluna à esquerda, trazemos os títulos dos livros Deuterocanônicos do NT, discutidos, mas que entraram e fazem parte do Cânon do NT; já na coluna à direita nós trazemos uma outra lista de livros bastante discutidos, mas que não entraram no Cânon do NT, embora vários Padres da Igreja os recomendassem e outros os tivessem até mesmo como canônicos. Cremos ser importante nunca nos esquecermos e termos presente que a opinião de um autor individualmente não tem o peso como a decisão de um Sínodo ou de Concílio, como é o caso que vamos tendo a partir do séc. IV, que vai definindo cada vez mais a Lista dos Livros tanto do AT como do NT para o Cristianismo, que para o AT vai seguindo seus caminhos a partir do Cânon Alexandrino (LXX/Grego, longo) e não do Cânon Palestinense (TANAK/ Hebraico, breve), e para o NT vai construindo o seu próprio Cânon de 27 livros a partir de suas várias decisões eclesiásticas, tanto Orientais como Ocidentais.

\footnotetext{
${ }^{29}$ Em breve deveremos lançar um livro contendo muitos Catálogos do Cânon Bíblico tanto dos Padres Orientais como dos Padres Ocidentais, bem como de Sínodos e Concílios, e igualmente de algumas Confissões de Fé Protestantes. Estes textos sairão em forma bilíngue, para que possamos ter os originais e a tradução em língua portuguesa.
} 


\begin{tabular}{|l|l|}
\hline \multicolumn{1}{|c|}{ Deuterocanônicos do NT } & \multicolumn{1}{c|}{ Apócrifos do NT } \\
\hline 1. Epístola aos Hebreus & 8. Pastor de Hermas \\
2. Epístola de Tiago & 9. Apocalipse de Pedro \\
3. Segunda Epístolas de Pedro & 10. Epístola de Barnabé \\
4. Segunda Epístola de João & 11. Didaqué (Doutrina dos Apóstolos) \\
5. Terceira Epístola de João & 12. Epístola de Clemente \\
6. Epístola de Judas & \\
7. Apocalipse de João & \\
\hline
\end{tabular}

\section{Livros mais discutidos do NT: Deuterocanônicos e Apócrifos}

Na tabela aqui abaixo ${ }^{30}$, a primeira coisa que oferecemos é uma lista dos livros mais discutidos nos primeiros séculos da Igreja no que diz respeito ao NT, sendo que entre eles temos 5 Epístolas Católicas (Tiago, 2 Pedro, 1 e 2 de João, Judas), a Carta aos Hebreus e o livro do Apocalispe, que entraram no Cânon do NT, hoje comum às grandes Igrejas, e outros que não entraram (Pastor de Hermas, Apocalipse de Pedro, Epístola de Barnabé, Didaqué e Epístola de Clemente): a letra "S" indica que o livro é "Sim" listado como Sagrada Escritu$\mathrm{ra}$; a letra "D" indica que o autor enumera aquele livro em uma classe de livros em "Disputa"; a letra "P" indica que a lista "Pode" ser interpretada de forma a incluir o livro como Sagrada Escritura; a letra " $N$ " indica que o livro definitivamente "Não" entrou naquela lista, ou seja, que ele é expressamente rejeitado por aquele autor; a letra "A" significa que o livro está "Ausente", ou seja, que o autor não menciona o livro, o que implica a sua rejeição.

\begin{tabular}{|l|c|c|c|c|c|c|c|c|c|c|c|c|}
\hline Grego/Latim/Siríaco & Data & Heb & Tg & Pd & Jo & Jd & Ap & Past & ApP & Barn & Did & Clem \\
\hline Frag. Muratoriano & 170 & A & A & A & P & S & S & N & D & A & A & A \\
\hline Orígenes & 240 & S & D & D & D & D & S & A & A & A & A & A \\
\hline Eusébio de Cesareia & 324 & S & D & D & D & D & D & N & N & N & N & A \\
\hline Cirilo de Jerusalém & 348 & S & S & S & S & S & A & A & A & A & A & A \\
\hline Lista de Cheltenham & 360 & A & A & S & S & A & S & A & A & A & A & A \\
\hline Concílio de Laodicea & 360 & S & S & S & S & S & A & A & A & A & A & A \\
\hline Atanásio de Alexandria & 367 & S & S & S & S & S & S & N & A & A & D & A \\
\hline Anfilóquio de Icônio & 380 & S & D & D & D & D & D & A & A & A & A & A \\
\hline Cânon Apostólico & 380 & S & S & S & S & S & A & A & A & A & A & S \\
\hline Concílio Romano & 382 & S & S & S & S & S & S & N & A & A & A & A \\
\hline Epifânio & 385 & S & S & S & S & S & S & A & A & A & A & A \\
\hline
\end{tabular}

${ }_{30}$ Tabela parecida podemos encontrar no site http://www.bible-researcher.com/canon5.html, porém com cânones a menos e não na mesma ordem (questão de data), além de que aqui também temos Didaqué. 


\begin{tabular}{|l|c|c|c|c|c|c|c|c|c|c|c|c|}
\hline Gregório de Nazianzo & 385 & S & S & S & S & S & A & A & A & A & A & A \\
\hline Jerônimo & 390 & S & S & S & S & S & S & A & A & A & A & A \\
\hline Agostinho & 393 & S & S & S & S & S & S & A & A & A & A & A \\
\hline $3^{\circ}$ Concílio de Cartago & 397 & S & S & S & S & S & S & A & A & A & A & A \\
\hline Rufino de Aquileia & 400 & S & S & S & S & S & S & N & A & A & A & A \\
\hline Codex Claromontanus & 400 & S & S & S & S & S & S & S & S & S & S & A \\
\hline Versão Peshita Siríaca & 400 & S & S & A & A & A & A & A & A & A & A & A \\
\hline Versão Latina Vulgata & 400 & S & S & S & S & S & S & N & N & N & N & N \\
\hline Carta de Inocente I & 405 & S & S & S & S & S & S & A & N & A & A & A \\
\hline Decreto de Gelásio & 492 & S & S & S & S & S & S & N & A & A & A & A \\
\hline Relatório de Junílio & 550 & S & D & D & D & D & D & A & A & A & A & A \\
\hline Isidoro de Sevilha & 625 & S & S & S & S & S & S & A & A & A & A & A \\
\hline João Damasceno & 730 & S & S & S & S & S & S & A & A & A & A & A \\
\hline
\end{tabular}

\section{O arranjo/sequência dos textos do Cânon do NT}

Neste item nós queremos ver o arranjo geral dos livros do $\mathrm{NT}^{31}$, ou seja, como eles são distribuídos e os encontramos em alguns dos Padres da Igreja (Orientais e Ocidentais), bem como em alguns Códices e algumas Versões antigas. A nossa intenção é oferecer várias Listas a fim de que possamos ter uma ideia mais ampla de como o Corpus Paulinum foi citado no conjunto dos livros do NT, indicando o seu grau de valor, maior ou menor, conforme a ordem em que ele aparece no Catálogo ${ }^{32}$. Basta correr os olhos abaixo e vamos ver, por exemplo, que João Crisóstomo coloca as Cartas Paulinas como primeiro conjunto dos livros do NT e, em seguida, então cita os Evangelhos, Atos e as Cartas Católicas, omitindo o Apocalipse, coisa comum entre os Orientais. Também é interessante observar que outros colocam Paulo após as Católicas ou no final da Lista dos livros do NT, como Marcião ${ }^{33}$, Orígenes,

\footnotetext{
${ }^{31}$ Recordamos que nós tomamos apenas alguns dos vários Catálogos dos livros bíblicos que temos a respeito do Cânon do Novo Testamento, que traremos em breve em nosso livro que será publicado com muitos dos Catálogos Antigos, bem como de Catálogos medievais e contemporâneos, católicos e protestantes, com textos bilíngues, a fim de poder oferecer ao público interessado um texto que sirva como referencial para consulta, seja pelos muitos Catálogos seja pela ampla Bibliografia a respeito da temática.

${ }^{32}$ Fato está que a ordem em que as Cartas Paulinas vêm citadas antes das Cartas Católicas, revela também o seu grau de valor que foi dado aos ensinamentos deixados por Paulo Apóstolos sobre os demais, no que diz respeito às Cartas não paulinas do NT. Para tanto, sugerimos conferir GOSWELL, G. "The Order of the Books of the New Testament”, pp. 235-240.

${ }^{33}$ É sempre bom recordar que Marcião só aceita Lucas e 10 Cartas Paulinas, recusando as Pastorais e Hebreus, além de todo o AT e demais livros do NT, pois ele quis expurgar o NT de todo vestígio judaico (anti-judaico).
} 
Irineu, Códice Alexandrino, Códice Vaticano, Concílio de Laodiceia, Concílio de Antioquia, Atanásio, Synopsis Scripturae Sacrae, Leôncio e o Anônimo in notis. Também podemos constatar que Paulo aparece antes das Cartas Católicas, como a imensa maioria dos textos que citamos abaixo, como Cânon Muratoriano, Irineu, Códice Sinaítico, Códice Claromontano, Clemente de Alexandria, Tertuliano, Gregório de Naziano, Vulgata e Peshita.

Realmente é muito interessante ver como cada Padre da Igreja ou cada decisão de uma Igreja local ou de um Sínodo vai definindo a ordem em que os livros do NT vão sendo admitidos no uso litúrgico e na vida catequética de cada Comunidade da época, seja no Oriente seja no Ocidente. Igualmente é importante conferir como os manuscritos vão colocando a ordem dos livros, como os vários Códices (Vaticanus, Sinaiticus, Alexandrinus etc.) e ainda as Versões Antigas (Vulgata, Peshita, Copta, Armena, Gerorgiana etc.). Isso tudo vai nos mostrando a riqueza da diversidade de cada comunidade que vai dando o seu valor aos escritos das Sagradas Escrituras a partir da apostolicidade, da catolicidade, da regula fidei e do uso litúrgico, critérios que vão colaborar e influenciar na aceitação ou não de cada livro ${ }^{34}$. Nós optamos por não separar o Corpus Ioanneum tendo em vista que ele se encontra espalhado em meio ao Corpus Biblicum do NT: Evangelho, Cartas e Apocalipse, onde é possível ver a ordem do mesmo.

\subsection{Arranjo Geral dos Corpora do NT}

a) Cânon Muratoriano, Irineu, Clemente de Alexandria, Tertuliano, Cipriano, Dídimo (o Cego), III Concílio de Cartago (Norte da África), Eusébio de Cesareia, Códice Sinaítico, Vulgata, Versão Copta, Versão Etiópica, Anfilóquio, Rufino, Hugo de São Vitor: Evangelhos, Atos, Paulo, Católicas e Apocalipse.

b) Jerônimo e Epifânio: Evangelhos, Paulo, Atos, Católicas e Apocalipse.

c) Agostinho, Inocente I, Cassiodoro, Isidoro e João de Salisbury: Evangelhos, Paulo, Católicas, Atos e Apocalipse.

d) Cânon Apostólico: Evangelhos, Paulo, Católicas e Atos.

e) Códice Alexandrino, Atanásio, Synopsis Scripturae Sacrae, Leôncio e João Damasceno: Evangelhos, Atos, Católicas, Paulo e Apocalipse.

\footnotetext{
${ }^{34}$ BARRERA, J. T. A Bíblia Judaica e a Bíblia Cristã. Introdução à história da Bíblia. Petrópolis: Vozes, 1999, pp. 297-298.
} 
f) Códice Vaticano, Concílio de Laodiceia: Evangelhos, Atos, Católicas e Paulo.

g) João Crisóstomo: Paulo, Evangelhos, Atos e Católicas.

h) Marcião: Lucas e Paulo.

i) Orígenes: Evangelhos, Apocalipse, Católicas e Paulo.

j) Versão Peshita: Evangelhos, Atos, Paulo e Católicas.

1) Concílio de Antioquia: Evangelhos, Católicas e Paulo.

m) Cânon de Cheltenham ou de Mommsen: Evangelhos, Paulo, Atos, Apocalipse e Católicas.

n) Gregório de Naziano e Versão Georgiana: Evangelhos, Atos, Paulo e Católicas.

o) Irineu: Evangelhos, Apocalipse, Católicas e Paulo.

p) Cânon Syríaco e Armena: Evangelhos, Atos, Paulo e Católicas.

q) Concílio Romano e Decreto Gelasiano: Evangelhos, Atos, Paulo, Apocalipse e Católicas.

r) Junílio: Evangelhos, Atos, Apocalipse, Paulo e Católicas.

s) Códice Claromontano: Evangelhos, Paulo, Católicas, Apocalipse e Atos.

t) Cirilo de Jerusalém e Anônimo in notis: Evangelhos, Atos, Católicas e Paulo.

u) Filastro, Nicéforo e Sessenta Livros: Evangelhos, Atos, Paulo e Católicas.

\subsection{Arranjo do Corpus Evangelicorum}

a) Cânon Muratoriano, Orígenes, Eusébio, Cirilo, Irineu, Clemente de Alexandria, Tertuliano, Cipriano, Dídimo (o Cego), Concílio de Laodiceia, Atanásio, Gregório de Nazianzo, Anfilóquio, Cânon Apostólico, Concílio de Antioquia, Concílio Romano, Decreto Gelasiano, Epifânio, Jerônimo, Agostinho, III Concílio de Cartago, Rufino, Inocente I, Filastro, Códice Vaticano, Códice Sinaítico, Códice Alexandrino, Synopsis Scripturae Sacrae, Patriarca Nicéforo, Junílio, Cassiodoro, Isidoro, Leôncio, Sessenta Livros, João Damasceno, Hugo de São Vitor, João de Salisbury, Anônimo in notis; Versões Peshita/ Syriaca, Vulgata, Armena, Copta, Etiópica e Georgiana: Mateus, Marcos, Lucas e João.

b) Cânon de Cheltenham/Mommsen: Mateus, Marcos, João e Lucas. 
c) Cânon Claromontano: Mateus, João, Marcos e Lucas.

d) João Crisóstomo: João, Mateus, Lucas e Marcos.

e) Marcião: Lucas

\subsection{Arranjo do Corpus Paulinum}

a) Marcião: Gálatas, Coríntios, Romanos, Tessalonicenses, Laodicenses (Efésios), Colossenses, Filipenses e Filemon.

b) Cânon Muratoriano: Coríntios, Efésios, Filipenses, Colossenses, Gálatas, Tessalonicenses, Romanos, Filemon, Tito e Timóteo.

c) Concílio de Laodiceia, Atanásio, Jerônimo, Synopsis Scripturae Sacrae, Códice Sinaítico, Códice Alexandrino: Romanos, Coríntios, Gálatas, Efésios, Filipenses, Colossenses, Tessalonicenses, Hebreus, Timóteo, Tito e Filemon.

e) Agostinho, Cassiodoro: Romanos, Coríntios, Gálatas, Efésios, Filipenses, Tessalonicenses, Colossenses, Timóteo, Tito, Filemon e Hebreus.

f) Tertuliano, Anfilóquio, Junílio, Anônimo in notis; Versão Peshita-Syriaca, Copta, Etiópica, Georgiana: Romanos, Coríntios, Gálatas, Efésios, Filipenses, Colossenses, Tessalonicenses, Timóteo, Tito, Filemon, Hebreus

g) Cânon Claromontano: Romanos, Coríntios, Gálatas, Efésios, Timóteo, Tito, Colossenses e Filemon.

h) Concílio Romano e Decretum Gelasianum: Romanos, Coríntios, Efésios, Tessalonicenses, Gálatas, Filipenses, Colossenses, Timóteo, Tito, Filemon, Hebreus.

i) Orígenes, Eusébio de Cesareia: Cartas de Paulo, mas não as cita e nem o número:

j) Cheltenham/Mommsen, Filastro: 13 Epístolas de Paulo (sem Hebreus)

1) Cirilo de Jerusalém, Gregório de Nazianzo, Cânon Apostólico, Epifânio, III Concílio de Cartago, Rufino, Inocente I, João Crisóstomo, Patriarca Nicéforo, Leôncio, João Damasceno, Hugo de São Vitor, João de Salisbury: 14 Epístolas de Paulo (13 + Hebreus).

m) Sessenta Livros: Romanos, Coríntios, Gálatas, Efésios, Filipenses, Colossenses, Tessalonicenses, Filemon, Timóteo, Tito, Hebreus.

n) João de Salisbury: 15 Epístolas de Paulo (13 + Hebreus e Laodicenses). 
o) Irineu, Clemente de Alexandria, Cipriano, Dídimo (o Cego): Romanos, Coríntios, Gálatas, Efésios, Filipenses, Colossenses, Tessalonicenses, Timóteo, Tito e Hebreus.

p) Concílio de Antioquia: Romanos, Coríntios, Gálatas, Efésios, Filipenses, Colossenses, Hebreus, Tessalonicenses, Timóteo, Tito e Filemon.

q) Códice Vaticano: Romanos, Coríntios, Gálatas, Efésios, Filipenses, Colossenses, Tessalonicenses, Hebreus (omite Timóteo, Tito e Filemon)

r) Versão Vulgata: Romanos, Coríntios, Gálatas, Tessalonicenses, Efésios, Filipenses, Colossenses, Timóteo, Tito, Filemon, Hebreus.

\subsection{Arranjo do Corpus Catholicum}

a) Cirilo de Jerusalém, Concílio de Laodiceia, Concílio de Antioquia, Atanásio, Gregório de Nazianzo, Epifânio, Jerônimo, Synopsis Scripturae Sacrae, Patriarca Nicéforo, Leôncio, Sessenta Livros, João Damasceno, Hugo de São Vitor, Anônimo in notis, Códice Sinaítico, Codíce Alexandrino, Códice Vaticano; Versões Vulgata, Armena e Georgiana: Tiago, 1 e 2 de Pedro, 1, 2 e 3 de João, Judas.

b) Concílio de Cartago: 1 e 2 de Pedro, 1, 2 e 3 de João, Tiago e Judas.

c) Concílio Romano, Decreto Gelasiano, Cânon Claromontano: 1 e 2 de Pedro, Tiago, 1, 2 e 3 de João, Judas.

d) Agostinho, Rufino: 1 e 2 de Pedro, Tiago, Judas, 1, 2 e 3 de João.

e) Inocêncio I, Isidoro: 1, 2 e 3 de João, 1 e 2 de Pedro, Judas, Tiago.

f) Filastro; Versões Copta e Eiópica: 1 e 2 de Pedro, 1, 2 e 3 de João, Judas, Tiago.

g) Cânon Muratoriano: Judas, duas de João.

h) Orígenes: Pedro, João.

i) Eusébio: 1 João, 1 Pedro, Tiago, Judas, 2 Pedro, 2 e 3 João.

j) Cheltenham/Mommsen: três de João, duas de Pedro.

1) Anfilóquio: Tiago, três de João, duas Pedro, Judas.

m) Cânon Apostólico: Tiago, três de João, Judas, duas de Pedro.

n) João Crisóstomo: "das Epístolas católicas há três" (Tiago, 1 Pedro, 1 João)

o) Relatório de Junílio: 1 Pedro, 1 João, Tiago, 2 Pedro, Judas, duas de João. 
p) Cassiodoro oferece duas listas, uma como sendo de Jerônimo, na seguinte ordem: 1 e 2 de Pedro, 1, 2 e 3 de João, Tiago e Judas; e outra como sendo de Agostinho, na seguinte ordem: 1 e 2 de Pedro, 1, 2 e 3 de João, Judas, Tiago.

q) João Salisbury: cita apenas o título: "seguem as 7 Epístolas Canônicas"

r) Marcião: recusa todas as cartas católicas.

s) Irineu, Cipriano de Cartago: Tiago, 1 Pedro, 1-2 João.

t) Clemente de Alexandria, Dídimo (o Cego): Tiago, 1 Pedro, 1 João, Judas.

u) Tertuliano, Versão Peshita: Tiago, 1 Pedro, 1 João.

\section{Datas aproximadas de Composição dos textos do NT}

Datar a escrituração dos textos bíblicos constitui, em alguns casos, uma empreitada gigantesca, seja para livros do AT seja para livros do NT. Diante disso, optamos por oferecer aqui uma datação para os livros do NT que nos é indicada por R.E. Brown e R.F. Collins ${ }^{35}$, onde encontramos dois gráficos ilustrativos e que nos indicam as possibilidades, sem fechar a questão, visto que alguns textos ainda permanecem com a discussão em aberto. Com certeza outros autores poderão indicar outras datas, mas que também vão ser aproximativas e nunca de certeza matemática, cronologicamente falando, inclusive sobre a própria vida e ação evangelizadora do Apóstolo dos Gentios ${ }^{36}$. Além, disso recordamos que a ordem que encontramos no Cânon Paulino não é cronológica e sim de extensão, por tamanho ${ }^{37}$, como já indicamos acima, e outros falam também de ordem de valor temático ou doutrinário. Fato está que, se observarmos, vamos perceber que a questão da extensão da carta está bem

\footnotetext{
${ }^{35}$ BROWN, R. E.; COLLINS, R. F. "O Cânone do Novo Testamento”, p. 928.

${ }^{36}$ A fim de uma visão das dificuldades de se estabelecer uma cronologia de Paulo, suas viagens missionárias e seus escritos, sobretudo por causa de suas duas fontes (Atos e Cartas), sugerimos conferir os textos de ALEXANDER, L. C. A. "Cronologia de Paulo". In: HAWTHORNE, G. F.; MARTIN, R. P.; REID, D. G. (Orgs.). Dicionário de Paulo e suas Cartas. São Paulo: Vida Nova-Paulus-Loyola, 2008, pp. 343-353; MURPHY-O'CONNOR, J. Paulo, Biografia Crítica. São Paulo: Loyola, 2000, pp. 17-46; KUMMEL, W. G. Introdução ao Novo Testamento. São Paulo: Paulinas, 1982, pp. 322-326; BROWN, R. E. Introdução ao Novo Testamento. São Paulo: Paulinas, 2004, pp. 573-583; BORING, M. E. Uma Introdução ao Novo Testamento, pp. 301-344; SACCHI, A. e Collaboratori. Lettere Paoline, pp. 61-68.

${ }^{37}$ GOSWELL, G. "The Order of the Books of the New Testament", p. 237.
} 
representada, uma vez que de Romanos, a mais extensa, até Filemon, a mais curta, realmente temos uma ordem de grandeza e não apenas temática, e muito menos cronológica.

\begin{tabular}{|c|c|c|c|c|c|c|}
\hline $\begin{array}{c}\text { Início } \\
\text { dos anos } 50\end{array}$ & $\begin{array}{c}\text { Metade/ } \\
\text { Final dos } \\
\text { anos } 50\end{array}$ & $\begin{array}{c}\text { Início } \\
\text { dos anos } 60\end{array}$ & $\begin{array}{c}\text { Metade } \\
\text { dos anos } 60\end{array}$ & $\begin{array}{c}\text { Anos } \\
70-80\end{array}$ & $\begin{array}{c}\text { Anos } \\
90\end{array}$ & $\begin{array}{c}\text { Após } \\
0 \text { ano } \\
100\end{array}$ \\
\hline 1 Tessalonicenses & Gálatas & Filemon (?) & Marcos & Mateus & João & 2 Pedro \\
\hline \multirow[t]{10}{*}{2 Tessal. (?) } & 1 Coríntios & Colossenses (?) & Tito (?) & Lucas & Apocalipse & \\
\hline & 2 Coríntios & Efésios (?) & 1 Timóteo (?) & Atos & 1 João & \\
\hline & Romanos & & 2 Timóteo (?) & Colossenses (?) & 2 João & \\
\hline & Filipenses & & 1 Pedro (?) & Judas (?) & 3 João & \\
\hline & Filemon (?) & & Tiago (?) & Tiago (?) & Judas (?) & \\
\hline & & & Hebreus (?) & Hebreus (?) & 2 Tessal. (?) & \\
\hline & & & & 1 Pedro (?) & Efésios (?) & \\
\hline & & & & & Tito (?) & \\
\hline & & & & & 1 Tim. (?) & \\
\hline & & & & & 2 Tim. (?) & \\
\hline
\end{tabular}

\begin{tabular}{|c|c|c|c|c|c|c|}
\hline \multicolumn{3}{|c|}{ Corpus Paulino } & \multicolumn{2}{|c|}{ Evangelhos } & \multicolumn{2}{|c|}{ Epístolas Católicas } \\
\hline $\begin{array}{c}\text { Primeiras } \\
\text { Cartas }\end{array}$ & $\begin{array}{l}1 \text { Tessalonic. } \\
2 \text { Tessalonic. }\end{array}$ & $\begin{array}{l}51 \\
51 \text { ou anos } \\
90\end{array}$ & $\begin{array}{r}\text { Marcos } \\
\text { Mateus } \\
\text { Lucas } \\
\text { João }\end{array}$ & \begin{tabular}{|l}
$65-70$ \\
anos $70-80$ \\
anos $70-80$ \\
anos 90
\end{tabular} & $\begin{array}{l}\text { 1Pedro } \\
\text { Tiago } \\
\text { Judas } \\
1 \text { João } \\
2 \text { João } \\
3 \text { João } \\
2 \text { Pedro }\end{array}$ & $\begin{array}{l}64 \text { ou anos } 70-80 \\
62 \text { ou anos } 70-80 \\
\text { anos } 70-90 \\
\text { anos } 90 \\
\text { anos } 90 \\
\text { anos } 90 \\
\text { anos } 100-150\end{array}$ \\
\hline $\begin{array}{l}\text { Grandes } \\
\text { Cartas }\end{array}$ & $\begin{array}{r}\text { Gálatas } \\
\text { Filipenses } \\
1 \text { Coríntios } \\
2 \text { Coríntios } \\
\text { Romanos }\end{array}$ & \multicolumn{2}{|l|}{$\begin{array}{l}54-57 \\
56-57 \\
57 \\
57 \\
58 \\
\end{array}$} & & & \\
\hline $\begin{array}{c}\text { Cartas } \\
\text { escritas na } \\
\text { prisão }\end{array}$ & $\begin{array}{r}\text { Filêmon } \\
\text { Colossenses } \\
\text { Efésios }\end{array}$ & \multicolumn{2}{|c|}{$\begin{array}{l}56-57 \text { ou } 61-63 \\
61-62 \text { ou } 70-80 \\
61-63 \text { ou } 90-100\end{array}$} & $\begin{array}{r}\text { Outros } \\
\text { Escritos }\end{array}$ & $\begin{array}{r}\text { Atos } \\
\text { Hebreus } \\
\text { Apocalipse }\end{array}$ & $\begin{array}{l}\text { Anos } 70-80 \\
\text { Anos } 60 \text { ou anos } \\
70-80 \\
\text { Anos } 90\end{array}$ \\
\hline $\begin{array}{c}\text { Cartas } \\
\text { Pastorais }\end{array}$ & $\begin{array}{r}\text { Tito } \\
1 \text { Timóteo } \\
2 \text { Timóteo }\end{array}$ & \multicolumn{2}{|c|}{$\begin{array}{l}65 \text { ou } 95-100 \\
65 \text { ou } 95-100 \\
66-67 \text { ou } 95-100\end{array}$} & & & \\
\hline
\end{tabular}




\section{Conclusão}

Estudar a ordem e o arranjo dos textos pertencentes ao Corpus Paulinum dentro de todo o Corpus Biblicum do NT, conferir os textos e tentar conhecer um pouco mais sobre seu trajeto para se pertencer definitivamente no Cânon do NT, bem como sua colaboração para toda a Teologia Bíblica do NT é algo que constitui um prazeroso desafio.

Como vimos desde nossa introdução, as Cartas Paulinas formam um conjunto que encontrou logo cedo boa aceitação entre os livros Canônicos do NT. Elas apenas tiveram diferença na ordem de citação no arranjo do Cânon entre os textos do NT: entre os Orientais, citando-as após o Cânon das Cartas Católicas, e os Ocidentais citando-as antes das Cartas Católicas, como temos até hoje em nossas Bíblias. Outro pequeno problema foi a aceitação da autoria da Carta aos Hebreus, ora citada como paulina ora citada como não paulina, como a temos hoje, onde ela já aceita como de não autoria paulina e sim desconhecida.

A aceitação do conjunto do Corpus Paulinum é unânime ainda hoje, uma vez que católicos, ortodoxos e protestantes aceitam todas as cartas e na ordem em que se encontram em nossas Bíblias modernas. A única questão que ainda permanece como um desafio é a questão da autoria das Cartas Paulinas: as autenticamente Paulinas, as Deuteropaulinas e as Pastorais, desafio este que ainda vai perdurando nas mãos de nossos muitos estudiosos, até que se encontrem novas indicações de maior aceitação ou recusa da autoria paulina de cada uma destas cartas que ainda são duvidosas.

Por fim, a história do Cânon do NT nos revela que alguns textos encontraram dificuldades para serem aceitos como canônicos, e isso já no início do cristianismo, que foi definindo o seu Cânon do NT e respeitando o Cânon do AT, que a Igreja Primitiva já usava e o tinha em alta estima. Estes textos que encontraram dificuldades para entrar no Cânon Bíblico foram chamados pela Igreja Católica de Deuterocanônicos do NT (Hebreus, Tiago, 2 Pedro, 2 e 3 de João, Judas e Apocalipse), e colocados em cheque novamente por alguns dos Reformadores, deixando-lhes um status inferior ${ }^{38}$, a exemplo dos sete Deuterocanônicos do $\mathrm{AT}^{39}$ (Tobias, Judite, 1 e 2 Macabeus, Baruque, Eclesiástico,

\footnotetext{
${ }^{38}$ Cf. BRUCE, F. F. O Cânon das Escrituras. São Paulo: Hagnos, 2013, pp. 219-228.

${ }^{39} \mathrm{Cf}$. METZGER, B. M. The Canon of the New Testament. Its Origen, Development, and Significance. Oxford: Clarendon Press, 2009, pp. 239-247.
} 
Sabedoria, além de Dn 3,24-90, Dn 13-14 e Est 10,4-16,24) 40 $^{\text {O grande desa- }}$ fio que permanece é aquele de redescobrir o valor das Cartas do NT no conjunto da Teologia Bíblica do NT e de todo o Corpus Biblicum. O futuro será promissor se nós formos bons investidores também neste campo, sem nunca deixar de cuidar dos demais campos bíblicos do NT e do AT como um todo.

\section{Referências bibliográficas}

AAGESON, J. W. "The Pastoral Epistles, Apostolic Authority, and the Development of the Pauline Scriptures". In: PORTER, S. E. The Pauline Canon. Atlanta: Society of Biblical Literature, 2009, pp. 5-26.

ALEXANDER, L. C. A. "Cronologia de Paulo". In: HAWTHORNE, G. F.; MARTIN, R.P.; REID, D. G. (Orgs.). Dicionário de Paulo e suas Cartas. São Paulo: Vida Nova-Paulus-Loyola, 2008, pp. 343-353.

ATHANASIUS ALEXANDRINI. "Epistola XXXIX" In: MIGNE, J. P. Patrologia, series Grega, Tomus XXVI. Paris: Petit-Montrouge, 1857, pp. 1435-1438.

ARAGIONE, G. "La lettre festale 39 d'Athanase". In: ARAGIONE, G.; JUNOD, E.; NORELLI, E. (Dir.). Le Canon du Nouveau Testament. Regards nouveaux sur l'histoire de as formation. Genève: Labor et Fides, 2005, pp. 197-219.

AURELII AUGUSTINI. "Doctrina Christiana, Caput VIII: Libri canonici”. In: MIGNE, J. P. Patrologia Migne Latina, Tomus XXXIV. Paris: PetitMontrouge, 1841, pp. 40-41.

${ }^{40}$ O termo Deuterocanônico foi usado primeiramente por Sixto de Siena em 1566 (F. Sixtus Senensis: 1520-1569), para descrever textos do AT e do NT, que a Igreja Católica sempre usou como canônicos e reforçou sua posição, durante o Concílio de Trento (1545-1563), e que Lutero e outros Reformadores recusaram durante a Reforma Protestante do séc. XVI. Sixto era filho de pais judeus e se converteu ao cristianismo; ele entrou para a Ordem Franciscana e, mais tarde, passou para a Ordem Dominicana, deixando uma obra importante, intitulada Bibliotheca Sancta, onde tratou dos textos sagrados; e o termo Deuterocanônico significa segundo cânon ou segunda lista dos livros sagrados, em oposição àqueles chamados canônicos e que nunca foram colocados em cheque desde a antiguidade. Os protestantes os chamam e os tem como apócrifos (não canônicos). A ideia de Sixto de Siena foi a de identificar os livros que foram inseridos num primeiro momento no Cânon (proto-canônicos ou canônicos de primeira ordem) e os que foram inseridos num segundo momento no Cânon (deutero-canônicos ou canônicos de segunda ordem), indicando uma ordem cronológica de aceitação no Cânon das Escrituras e não de valor ou autoridade em termos de inspiração ou revelação, que ele aceitava. 
BALLARINI, T. "São Paulo e as suas Cartas em Geral”. In: BALLARINI, T. Introdução à Bíblia. Vol V/1. Petrópolis: Vozes, 1969, pp. 154-208.

BARRERA, J. T. A Bíblia Judaica e a Bíblia Cristã. Introdução à história da Bíblia. Petrópolis: Vozes, 1999.

BIBLIA SACRA. Vulgatae Editionis. Sixti V Pontificis Maximi et Clementis VIII. Paris: Bibliopolas, 1869.

BORING, M. E. Uma Introdução ao Novo Testamento: História, Literatura, Teologia. Questões Introdutórias do Novo Testamento e Escritos Paulinos. Vol. I. Santo André: Academia Cristã - Paulus, 2016.

BROWN, R. E. Introdução ao Novo Testamento. São Paulo: Paulinas, 2004.

BROWN, R. E.; COLLINS, R. F. "O Cânone do Novo Testamento". In: BROWN, R. E.; FITZMYER, J. A.; MURPHY, R. E. Novo Comentário Bíblico São Jerônimo do Novo Testamento e Artigos Sistemáticos. Santo André: Academia Cristã, 2011, pp. 925-940.

BRUCE, F. F. O Cânon das Escrituras. São Paulo: Hagnos, 2013.

CABAllerO, J. L. "El Canon Paulino. Consideraciones en torno a la naturaliza y la formación del Canon del Nuevo Testamento". Scripta Theologica 41 (2009/3), pp. 899-923.

CARROL, K. L. "The expansion of the Pauline Corpus". JBL 59 (1953), pp. 230-237.

CERFAUX, L.; CAMBIER, J. "O Corpus Paulino". In: ROBERT, A.; FEUILLET, A. Introdução à Bíblia. Vol. IV. Novo Testamento, Parte II: Corpus Paulino. Petrópolis: Vozes, 1968, pp. 3-15.

CINGOLANI, S. Dizionario di Critica Testuale del Nuovo Testamento. Storia, canone, aprocrifi, paleografia. Torino: San Paolo, 2008.

COTHENET, T. São Paulo e seu Tempo. São Paulo: Paulinas, 1985.

ENQUIRIDION BÍBLICO. Documentos de la Iglesia sobre la sagrada Escritura. Madrid: BAC, 2010.

EUSEBII HIERONIMY. “Epistola LIII”. In: MIGNE, J. P. Patrologia, series Latina, Tomus XXII. Paris: Petit-Montrouge, 1845, pp. 540-549.

FITZMYER, J. A. "Introdução às Epístolas do Novo Testamento". In: BROWN, R. E.; FITZMYER, J. A.; MURPHY, R. E. Novo Comentário 
Bíblico São Jerônimo do Novo Testamento e Artigos Sistemáticos. Santo André: Academia Cristã, 2011, pp. 399-405.

FOSTER, L. "The Earliest Collection of Paul's Epistles". BETS (1956), pp. 44-55.

GAMBLE, H. Y. "The Redaction of the Pauline Letters and the Formation of the Pauline Corpus". JBL 49 (1975), pp. 403-418.

GOSWELL, G. "The Order of the Books of the New Testament". JETS 53/2 (2010), pp. 225-241.

GREGORII THEOLOGI. "Theologica, Liber I, Sectio I, Poemata Dogmatica, Carmina XII”. In: MIGNE, J. P. Patrologia, series Grega, Tomus XXXVII. Paris: Petit-Montrouge, 1862, pp. 471-474.

HARDING, M. "Disputed and Undisputed Letters of Paul". In: PORTER, S.

E. The Pauline Canon. Atlanta: Society of Biblical Literature, 2009, pp. 129-168.

HOLMES, M. W. “Crítica Textual”. In: HAWTHORNE, G. F.; MARTIN, R.P.; REID, D. G. (Orgs.). Dicionário de Paulo e suas Cartas. São Paulo: Vida Nova-Paulus-Loyola, 2008, pp. 337-341.

KUMMEL, W. G. Introdução ao Novo Testamento. São Paulo: Paulinas, 1982.

LONA, H. Introducción a Pablo. El Autor, Las Cartas, El Paulinismo. Buenos Aires: Editorial Claretiana, 2011.

MANNUCCI, V. Bíblia, Palavra de Deus. Curso de introdução à Sagrada Escritura. São Paulo: Paulus, 2008.

METZGER, B. M. The Canon of the New Testament. Its Origin, Development, and Significance. Oxford: Clarendon Press, 2009.

MURPHY-O'CONNOR, J. Paulo, Biografia Crítica. São Paulo: Loyola, 2000.

NESTLE-ALAND. Novum Testamentum Graece. Ed. XXVIII. Stuttgart: Deutsche Bibelgesellschaft, 2012.

O'NEILL, J. C. "Paul Wrote some of all, but not all of any". In: PORTER, S. E. The Pauline Canon. Atlanta: Society of Biblical Literature, 2009, pp. 167-188.

PATZIA, A. G. “Cânon”. In: HAWTHORNE, G. F.; MARTIN, R. P.; REID, 
D. G. (Orgs.). Dicionário de Paulo e suas Cartas. São Paulo: Vida NovaPaulus-Loyola, 2008, pp. 169-177.

PORTER, S. E. "When and How was the Pauline Canon Compiled? An Assessment of Theories". In: PORTER S. E. The Pauline Canon. Atlanta: Society of Biblical Literature, 2009, pp. 95-127.

SACCHI, A. e Collaboratori. Lettere Paoline e Altre Lettere. Torino: Elle Di $\mathrm{Ci}, 1995$.

SANCHEZ BOSCH, J. Escritos Paulinos. Vol. 7. São Paulo: Ave Maria, 2002. WESTCOTT, B. F.; HORT, F. J. A. The New Testament in The Original Greek: London: Macmillan and Co. Limited, 1906.

Waldecir Gonzaga Doutor em Teologia Bíblica pela Pontifícia Universidade Gregoriana de Roma Professor do Departamento de Teologia da PUC Rio: graduação e pós-graduação Rio de Janeiro / RJ - Brasil E-mail: waldecir@hotmail.com / waldecir@puc-rio.com.br

Recebido em: 13/10/16 Aprovado em: 14/12/16 